\title{
Literature Review of Audit Opinion
}

\author{
Bin Lu \\ School of Management, Jinan University, Guangzhou, China \\ Email: jnulb429@163.com
}

How to cite this paper: Lu, B. (2020) Literature Review of Audit Opinion. Modern Economy, 11, 28-36.

https://doi.org/10.4236/me.2020.111004

Received: December 20, 2019

Accepted: January 6, 2020

Published: January 9, 2020

Copyright $\odot 2020$ by author(s) and Scientific Research Publishing Inc. This work is licensed under the Creative Commons Attribution International License (CC BY 4.0).

http://creativecommons.org/licenses/by/4.0/

\begin{abstract}
The influencing factors of audit opinions have always been the focus area of academic research. This article categorizes research by Chinese and international scholars, and analyzes the research status of audit opinions. Starting from the factors that affect audit opinions, they are divided into two aspects: Chinese and international, and they are discussed in order to find the commonality and characteristics of related research and provide a reference for in-depth research on audit opinions.
\end{abstract}

\section{Keywords}

Audit Opinion, Literature Review, Influencing Factors

\section{Introduction}

As the final result of CPA audit, the type of audit opinion is related to the company's financing in the capital market on the one hand, on the other hand, it is related to whether the investors and other relevant stakeholders can make a correct evaluation and decision on the company. Therefore, the type of audit opinion is influenced and concerned by the company's own quality, investors, government supervision departments, and even the accounting firm itself.

As an important field of audit research, Chinese and international academic circles have carried out long-term and effective research on the influencing factors of audit opinion types, among which international research has made a lot of meaningful exploration in theory and empirical aspects. In China, due to the special economic system and relatively imperfect market mechanism, coupled with the recovery of CPA audit in recent years, some scholars have done a lot of empirical research on the influencing factors of audit opinion and come to some conclusions. However, there are many factors that affect audit opinion, in the study of these different factors, due to the different national conditions and research perspectives, the research at Chinese and abroad will also form different 
conclusions.

\section{Literature Review of Audit Opinions}

\subsection{Review of International Documents on Audit Opinions}

\subsubsection{Audit Opinion and Financial Status of the Company}

International scholars mainly select the financial indicators reflecting the company's financial ability, such as profitability, solvency, asset operation and management ability, to test the impact of the indicators on the non-standard audit opinion. The conclusion is relatively consistent: the company's financial situation has a significant impact on the audit opinion. Clive Lennox (2002) had studied and proved that the probability of enterprises receiving non-standard audit opinions is positively related to financial leverage, and negatively related to their cash flow [1].

Chen and Church (1992) take the severity of the crisis of listed companies as the starting point, and conclude that when the crisis of listed companies becomes obvious (such as net loss, debt default, pending litigation), auditors are more likely to find the crisis of going concern, so they are more likely to issue non-standard audit opinions [2]. Lennox (2002), empirical research shows that companies with high liabilities have a high probability of receiving non-standard audit opinions due to the high risk of bankruptcy [3].

\subsubsection{Audit Opinion and Auditor Change}

Chow and Rice (1982), put forward the same view: the change of auditor has a positive correlation with the retained audit opinion of the most recent fiscal year before the change [4].

Lennox (2000) uses the British listed companies as the research sample, designs the audit opinion estimation model to estimate the types of audit opinions that the listed companies may receive when they do not change their auditors, and compares it with the audit opinion types after changing their auditors, and finds that the British listed companies have successfully realized the purchase of audit opinions.

Defond and Subramanyam (1998) concluded that even if the company changed the accounting firm or audit that provided audit services for it, the subsequent firms would still maintain a high degree of prudence in their statements [5].

\subsubsection{Audit Opinion and Scale of Accounting Firm}

Lennox, C. (2003) thought that the partner of the auditee's former accounting firm was an associated enterprise [3]. They found that such an associated enterprise was more likely to receive clean audit opinions, and receiving clean audit opinions would make the company feel that this association was more valuable.

The common conclusion of De Angelo (1981) and Dye (1993) is that the larger the accounting firm is, the higher the audit quality it provides. De Angelo (1981) found that the larger the size of the firm, the higher the reputation, so as 
to maintain a high degree of independence and professional judgment [6]. A large-scale firm can reduce its economic dependence on a certain customer and provide non-standard audit opinions. If the audit failure leads to the loss of the firm, the larger the scale, the greater the loss, that is to say, "deep pocket" effect. These reasons make the large-scale firm more cautious, and will issue more non-standard audit opinions, which means the higher the audit quality.

Through the empirical analysis of Chinese market from 1993 to 1996, Defond and T.J. Wong found that no matter single variable analysis or multi variable analysis was used, no matter the number of clients audited or the size of clients audited was taken as the base, the test result was that there was a significant positive correlation between the size of accounting firms and audit independence.

Lindsay (1988), through an empirical study of the Canadian market, concludes that the size of the firm will have an impact on the independence of the audit, and ultimately the type of audit opinion [7].

\subsubsection{Audit Opinion and Corporate Governance Structure}

Combing the international literature about audit opinion and corporate governance structure, we find that: the foreign research mainly starts from the audit committee member structure, corporate governance mechanism, management shareholding and overseas shareholding and so on, and studies their impact on audit opinion.

The conclusion is more uniform, that is, a good corporate governance structure may improve the quality of financial reports and reduce the possibility of being issued non-standard audit opinions.

Fama (1980) thinks that the board of directors is the governance center of modern enterprises [8]. The more perfect the corporate governance structure is, the higher the decision-making efficiency of the board of directors is, that is, the corporate governance structure affects the audit opinion issued by auditors.

The higher the ownership concentration of La. Porta (1999), the more likely the auditors are to issue non-standard opinions, because the higher the ownership concentration, the larger the shareholders will manipulate the financial statements, and the greater the probability of the audited issuing non-standard opinions.

Warfield et al. (1995), according to relevant research, a company with good governance can send a favorable signal to the registered accountant, that is, a good governance structure. The lower the probability of breaking the law, the lower the relative risk during the audit, and the greater the probability of the standard audit opinion received by the company.

Clen (2001), through research, shows that: listed companies improve the quality of their financial information by improving their intelligence level, and ultimately their probability of being issued non-standard audit opinion will be smaller. Taking the listed companies from 1998 to 1999 as the research object, Carcello and Neal (2003) found that the larger the proportion of independent directors in the company audit committee, the smaller the probability of receiv- 
ing non-standard audit opinions [9].

\subsubsection{Audit Opinion and Earnings Management}

The existence of principal-agent leads to the conflict of interest and information asymmetry among different stakeholders, which provides the possibility of earnings management. On the relationship between audit opinion and earnings management, there have been a large number of literature studies internationally. Generally speaking, this kind of research takes the manipulative accruals as the measurement index of earnings management, but so far there is no clear and consistent conclusion. Becker and Defond et al. (1998) found that audit plays a role in limiting earnings management, and high-quality audit is easier to find and report misstatements, which has a good effect on finding earnings management.

Eli and Ferdinand, et al. (2001) connected earnings management with audit opinion [10]. They first tested the effect of various earnings management measurement models, and then connected them with audit opinion types. They found that the higher the degree of earnings manipulation, the more likely to be qualified.

Contrary to the above conclusions, Butler and Leone et al. (2004) found that in the US market, the non-standard opinion was issued because the company's accrued profit was negative and the amount was huge, which had nothing to do with the company's earnings management [11].

\subsubsection{Audit Opinion and Internal Control}

Prior to SOX act, the disclosure of internal control information of listed companies was voluntary, and the academic research lacked public data, so the empirical research on internal control in foreign countries was limited. Since 2002, Section 404 of SOX Act requires audit and disclosure of internal control, and then there are more and more researches based on the background of the United States. Most studies have come to a consistent conclusion: the better the quality of internal control, the easier it is to receive standard audit opinions.

Beneish (2008) measured the quality of internal control with the guidance of internal control elements [12]. The research believed that the higher the quality of internal control of listed companies, the lower the risk of audit failure faced by auditors. This is helpful for auditors to issue standard audit opinions.

Doyle et al. (2007) examined the relationship between internal control deficiencies and the quality of accruals [13]. They found that companies with internal control deficiencies had lower quality of accruals. There is a direct relationship between earnings quality and audit opinion.

Recently, the research of Tahinakis, P and Samarinas, $m$ (2016) considers that audit opinion has significant market impact, which includes incremental information, while the size and financial situation of the company can significantly affect the content of incremental information of audit opinion [14].

These international documents all show that audit opinions have a significant 
impact on the market, and the market will give feedback based on the type of audit opinion, and these feedbacks are reflected in the microeconomic activities of enterprises.

\subsection{Chinese Literature Review of Audit Opinions}

\subsubsection{Audit Opinion and Financial Status of the Company}

The financial indicators selected by Chinese scholars are different. Most scholars choose the financial indicators such as profit and loss, net interest rate of total assets and stocks to replace the financial ability of listed companies, and study the relationship between them and the types of audit opinions, and get a more consistent conclusion: non-standard audit opinions and financial ability are significantly negatively related, that is, the financial ability of listed companies The better the strength is, the less likely it is to receive non-standard audit opinions.

According to Zhu Xiaoping and Yu Qian (2003), quick ratio, asset liability ratio, proportion of accounts receivable to total assets, years of listed companies and other factors are negatively related to the probability that listed companies receive non-standard audit opinions, while factors such as return on net assets, asset scale, cash flow ratio, ratio of goods to total assets and other factors are positively related to the probability that listed companies receive non-standard opinions [15].

Tang Lianjiong and Wang Zhenyi (2005) adopted three indicators to measure the financial status of an enterprise, namely profitability, debt repayment ability, and asset utilization [16]. The research found that the financial status of listed companies significantly affected the types of audit opinions they received. The worse the financial capability of a listed company, the more likely it is that a certified public accountant will issue a non-standard audit opinion.

Song Xiuchao, Liu Meiyue, (2010), through in-depth analysis of Listed Companies in household appliances industry, concluded that the larger the company's asset liability ratio index, the higher the possibility of being issued with non-standard audit opinions, the stronger the company's profitability, and the easier it is to receive standard audit opinions.

\subsubsection{Audit Opinion and Auditor Change}

Some Chinese scholars think that companies with opinion buying motivation can successfully achieve opinion buying, but the evidence is relatively weak. $\mathrm{Lu}$ Zhengfei and Tong pan (2003) also show that there is a significant correlation between auditor changes and audit opinions of the previous year, which shows that listed companies in China have the motivation to purchase audit opinions and try to improve audit opinions [17]. However, through the study of market reaction, it is found that there is no information increment in the information disclosure of auditor change, and there is no significant result in the market reaction (Li Shuang, Li Hui, Wu Xi, 2001) [18]. These two contradictory research results show that there is no clear conclusion in the field of audit opinion purchase in China. 


\subsubsection{Audit Opinion and Firm Size}

Qian Guangming and Chen Deyan (2014) took the listed companies that issued A shares on the main boards of Shanghai and Shenzhen stock markets as the statistical samples, and used the multivariate statistical analysis method to study the impact of the scale of accounting firms on the audit quality. The results show that there is a weak positive correlation between the size of accounting firms and audit quality.

Li Chuntao (2006) and Yu Peng (2007) concluded that "Big Institute" can perform audit business more independently and issue more strict audit opinions [19].

Liu Feng (2002), based on the in-depth study of the companies with non-standard audit opinions in 1998, put forward that the larger firms have stronger ability to issue more strict audit opinions [20].

However, some scholars have found that there is no significant correlation between audit opinions of firm size. For example, Xia Lijun and Yang Haibin (2002) found that: in China, early research in this field found that there was no significant relationship between the size of the firm and the audit opinion, and thus believed that the international "Big Four accounting firms" audit quality was not higher than "non Big Four accounting firms" [21].

\subsubsection{Audit Opinion and Corporate Governance Structure}

Recently, some Chinese scholars have focused on the relationship between corporate governance structure and audit opinion. However, there is no systematic theory in relevance research. Most scholars only study the impact of one aspect of corporate governance on audit opinion. Among them, the most studied are the ownership structure and the characteristics of the board of directors. Chen. (2001) based on the empirical study of China's stock market, believed that the higher the proportion of management shares and overseas shares, the more likely it is to improve the quality of financial reports and reduce the possibility of being issued with non-standard audit opinions [22]. Cai Chun, Yang Lin (2005) showed that the internal management quality characteristics of the company had a significant impact on the audit opinion [23].

\subsubsection{Audit Opinion and Earnings Management}

In China, the research on the correlation between earnings management and audit opinion has not reached a consensus conclusion. Some scholars in China, such as Xia Lijun (2002), pointed out that companies with higher earnings management have a higher probability of being issued non-standard audit opinions, which means that auditors can identify earnings management behavior of listed companies [24]. In contrast, research by Li Dongping (2001) and Wu Liansheng et al. (2011) shows that there is no significant correlation between earnings management and non-standard audit opinion.

\subsubsection{Audit Opinion and Internal Control}

Most of the related literatures about internal control and audit opinion think 
that the most direct economic consequence of the effectiveness of internal control is earnings quality. Yang Deming and Hu Ting (2010) found that the higher the quality of internal control is, the less likely CPAs are to find earnings management [25]. With the improvement of the quality of internal control of listed companies, the probability of CPAs issuing non-standard audit opinions on earnings management is significantly reduced. Yang Qunhui and Wang Yurong (2011) also investigated the relationship between internal control and audit opinion of listed companies, which was slightly different from the research methods of Yang Deming and others (2010). They used random matched samples and self-designed internal control scores, but the conclusions were similar. Xiao Chengmin and Li Rong (2012) used the latest internal control index after design adjustment to reflect the improvement of the effectiveness of internal control to a certain extent. The research conclusion is still consistent with the previous research, that is, the internal control of listed companies The weaker the validity, the higher the probability that its annual report will be issued a non-standard audit opinion by a certified public accountant [26].

\section{Literature Review}

Achievements of the research on audit opinions: 1) In the research on the financial indicators and audit opinions of the audited units, although the selection criteria are not completely the same at China and international, the conclusions are basically the same, that is, the financial situation of the listed companies is the key factor affecting the audit opinions. 2) In the study of corporate governance structure, firm size and audit opinion, the same conclusion has been drawn in foreign countries: firm size will have a great impact on the independence of certified public accountants, and then affect the type of audit opinion. And a good corporate governance structure is more likely to be issued with standard audit opinions. However, there is no clear conclusion on the research of these two factors in China. 3) In terms of the factors affecting the audit opinion, there are also differences in the research of scholars at home and abroad. If the non-standard audit opinion is issued in the previous period of the company, the current period is more inclined to change the audit firm or auditor who provides audit services for the company. However, the difference is also obvious, that is to say, international scholars think that after most companies change accounting firms or auditors, the audit opinion of this period has not been significantly improved, while Chinese scholars think that after most companies change accounting firms and auditors, the audit opinion of this period has been better improved. It formed the purchase of audit opinions. At present, there are two ways to divide audit opinion in the research of audit opinion at China and international one is to take standard unqualified audit opinion as standard audit opinion, the other is non-standard audit opinion. This is also the method adopted by most of the literature, and the conclusion is relatively stable. The second is to define the type of unqualified audit opinion as the standard unqua- 
lified audit opinion and the unqualified opinion with emphasis, and the rest as the non-standard audit opinion.

\section{Future Research Outlook}

There are still some shortcomings in this aspect of research. The Chinese and international literatures on audit opinions are focusing on how financial conditions, earnings management, and internal control affect audit opinions. Few focus on the relationship between corporate strategy and audit opinion. The emerging Internet business model can be regarded as the choice of corporate strategy. With this specific corporate strategy, the relationship between the two can be observed intuitively. On the other hand, due to the rise of the Internet, a large number of articles so far have analyzed this business model at the theoretical level, and there are few empirical studies related to it. This direction is a direction that can be in-depth research on the factors affecting audit opinions.

\section{Conflicts of Interest}

The author declares no conflicts of interest regarding the publication of this paper.

\section{References}

[1] Lennox, C. (2000) Do Companies Successfully Engage in Opinion-Shopping? Evidence from the UK. Journal of Accounting and Economics, 29, 321-337. https://doi.org/10.1016/S0165-4101(00)00025-2

[2] Chen, K and Church, B. (1992) Going Concern Opinions and the Market Reaction to Bankruptcy Filing. The Accounting Review, 71, 117-128.

[3] Lennox, C. (2005) Audit Quality and Executive Officers' Affiliations with CPA Firms. Journal of Accounting \& Economics, 39, 201-231. https://doi.org/10.1016/j.jacceco.2003.12.002

[4] Chow, C.W. and Steven, J.R. (1982) Qualified Audit Opinions and Auditor Switching. The Accounting Review, 20, 326-335.

[5] Defond, M.L., Raghunandan, K. and Subramanyam, K.R. (2002) Do Non-Audit Service Fees in Pair Auditor Independence? Evidence from Going Concern Audit Opinions. Journal Accounting Research, 40, 1247-1274. https://doi.org/10.2139/ssrn.297747

[6] De Angelo, E. (1981) Auditor Size and Audit Quality. Journal of Accounting and Economics, 3, 183-199. https://doi.org/10.1016/0165-4101(81)90002-1

[7] Lindsay, D. (1990) An Investigation of the Impact of Contextual Factors on Canadian Bankers' Perception of Auditors' Ability to Resist Management Pressure. Advance in International Accounting, 10.

[8] Fama, E.F. (1980) Agency Problems and the Theory of the Firm. The Journal of Political Economy, 88, 288-307. https://doi.org/10.1086/260866

[9] Carcello, J.V. and Neal, T.L. (2000) Audit Committee Composition and Auditor Reporting. The Accounting Review, 75, 453-467. https://doi.org/10.2139/ssrn.229835

[10] Bartov, E., Gul, F.A. and Tsui, J.S.L. (2001) Discretionary-Accruals Models and Au- 
dit Qualifications. Journal of Accounting and Economics, 30, 421-452. https://doi.org/10.2139/ssrn.214996

[11] Butler, M., Leone, A. and Willenborg, M. (2004) An Empirical Analysis of Auditor Reporting and Its Association with Abnormal Accruals. Journal of Accounting and Economics, 37, 139-165. https://doi.org/10.1016/j.jacceco.2003.06.004

[12] Beneish, M.D., Billings, M.B. and Hodder, L.D. (2008) Internal Control Weakness and Information Uncertainty. The Accounting Review, 83, 665-703. https://doi.org/10.2308/accr.2008.83.3.665

[13] Doyel, J., Ge, W. and McVay, S. (2007) Determinants of Weakness in Internal Control over Financial Reporting. Journal of Accounting and Economics, 44, 193-223. https://doi.org/10.1016/j.jacceco.2006.10.003

[14] Tahinakis, P. and Samarinas, M. (2016) The Incremental Information Content of Audit Opinion. Journal of Applied Accounting Research, 17, 139-169. https://doi.org/10.1108/JAAR-01-2013-0011

[15] Zhu, X.P. and Yu, Q. (2003) Empirical Test on the Correlation between Financial Indicators and Audit Opinion Types of Listed Companies. China Accounting Review, 1, 30-48.

[16] Tang, L.J. and Wang, Z.Y. (2005) Determinants of Audit Opinions in China's Securities Market. Journal of Hebei Normal University of Science \& Technology, Social Science, 4, 15-18.

[17] Lu, Z.F. and Tong, P. (2003) Auditing Research on Audit Opinions, Auditor Changes and Supervision Policies. Audit Research, No. 3, 30-35.

[18] Zhang, J.R., Liu, H. and Yang, B. (2015) Research on the Influence of Pending Litigation on Audit Fees and Audit Opinion Types. Audit Research, No. 1, 67-74.

[19] Li, C.T., Song, M. and Huang, M.L. (2006) Determinants of Audit Opinions: Evidence from Chinese Listed Companies China Accounting Review. China Accounting Review, 4, 345-354.

[20] Zhang, Y.K. and Liu, F. (2002) Empirical Research on the Relativity of Earnings Management and Audit Opinions. China Accounting and Finance Research, No. 3 , $1-29$.

[21] Xia, L.J. and Yang, H.B. (2002) CPA's Response to Earnings Management of Listed Companies. Audit Research, No. 4, 28-34.

[22] Chen, C.J.P., Chen, S.M. and Su, X.J. (2001) Profitability Regulation, Earnings Management and Modified Audit Opinions. Auditing. A Journal of Practice and Theory, 20, 9-30. https://doi.org/10.2308/aud.2001.20.2.9

[23] Cai, C., Yang, L., Chen, X.Y. and Chen, Y.H. (2005) Empirical Analysis on the Influencing Factors of Audit Opinion Types of Listed Companies-Based on the Annual Report of a Shares in Shanghai and Stock Market in Shenzhen. Financial science, No. 1, 95-102.

[24] Bo, X.H. and Wu, L.S. (2011) Earnings Management, Information Risk and Audit Opinion. Audit Research, No. 1, 90-97.

[25] Yang, D.M. and Hu, T. (2010) Internal Control, Earnings Management and Audit Opinions. Audit Research, No. 5, 90-97.

[26] Xiao, C.M. and Li, R. (2012) Does Internal Control Affect Audit Opinion? Accounting and Economic Research, No. 2, 34-41. 